\title{
The New Globalism:Reflections on the EU and the USA in Asia
}

\author{
RUTH A. BEVAN \\ Yeshiva University \\ rabevan@yu.edu
}

\begin{abstract}
The basic thesis of this paper is that Southeast Asia will be the crucible and the testing ground for a new Euro-American partnership. Both the United States and the European Union have vital interests in Southeast Asia. These interests certainly involve economics. They definitely concern security issues. And, for both the United States and the European Union, though for similar reasons differently nuanced, these interests aspire to the realm of ideals and idealism, of norms and normativism.
\end{abstract}

Keywords: ASEAN, Civilian Power, Multilateralism, Regionalism, Soft Power

\section{The New Globalism and Power}

The present global economic crisis camouflages the underlying technological revolution transforming us all - including the framework of our global relations. Information technology is engendering wholesale structural change economically and socially at historically unprecedented breakneck speed. Jobs lost, for example, in the United States during this recession of some three years will, for the most part, be lost in the dustbin of history. The workers who once toiled at those jobs, if they cannot be retrained, and most will not be able to be retrained for reasons of age or available skill sets, will find themselves sidelined. To expect the world to right itself according to previous standards of normalcy is to whistle in the dark. Change now occurs at a faster clip than at any time since the sixteenth century. An individual born today can expect to experience several lifetimes worth of change within his own lifespan. We now begin to probe the impact of the computer upon our brains and upon genetic selection. Are we moving to a new evolutionary rung? Within this context how could the global order itself not be transformed? 
Certain postulates about our global order can be made. We are moving light years away from a Eurocentric world order which held sway from roughly the eighteenth century to World War I. New powers, especially in Asia, are rising on the horizon. Social media empower the masses, whether it be in the Arab Spring or the Occupy Wall Street Movement and these social media operate globally. Individuals now traverse the globe not simply as tourists but as job-seekers and as house hunters. Higher education has turned transnational: students study in foreign countries and universities establish centers abroad. Increasingly, individuals work from home via personal computers.

Movement and change characterize our time. Both variables have iconoclastic tendencies. Boundaries wither. Identities expand. Loyalties grow complex. Perspectives hybridize. Personal tastes relish novelty. And new geographic hot spots emerge. In his book Monsoon Robert D. Kaplan writes that "the Greater Indian Ocean, stretching eastward from the Horn of Africa past the Arabian Peninsula, the Iranian plateau, and the Indian subcontinent, all the way to the Indonesian archipelago and beyond, may comprise a map as iconic to the new century as Europe was to the last one." ${ }^{1}$ Kaplan notes that in and around the Indian Ocean the rivalry between the United States and China interlocks with the regional rivalry between China and India. Also any United States' strike against Iran in its effort to contain Iran "will have an Indian Ocean address.”2 Southeast Asia finds its home in the Indian Ocean.

In November 2011 President Barack Obama of the United States visited Indonesia. He gave a strong, singular message: the United States must secure tighter relations with Southeast Asia. Having spent childhood years in Jakarta, Obama has personal ties to Indonesia that might explain his political orientation. But this factor alone does not suffice to explain foreign policy emphasis. The United States has a Pacific Ocean coastline. It has had a history of involvement politically and economically in Asia. Mark Philip Bradley in his book, Imaging Vietnam and America, details the fascination Vietnamese anti-colonial revolutionaries like Ho Chi Minh, who visited New York City in 1912, had for the American political model at the turn of the twentieth century. The United States, after all, had fought and won a war against British colonialism. The United States sharply criticized French colonialism in Indochina. It held up its own success in the Philippines as the alternative model to what it considered the French bureaucratic colonial nightmare and failure. While the United States reinstated the French in Indochina after World War II, rather than working with nationalist figures like Ho Chi Minh who then gravitated into the Soviet orbit, United States-French relations soured after the French defeat at Dien Bien Phu in 1954 and, certainly, during the subsequent American military involvement from 1955-1975 (fall of Saigon). In short, the United States stood forth as an attractive alternate Western model - commercial, pragmatic (as opposed to philosophical like the French) and revolutionary. Asians either admired this model, like Vietnam, or feared its consequences for Asia, like China and Japan as dominant Asian powers.

\footnotetext{
${ }^{1}$ R. D. Kaplan. Monsoon. New York, Random House. 2010. p. xi.
}

${ }^{2}$ Ibid, p. 9. 
Today the United States exports more than $\$ 50$ billion in goods to ASEAN countries per year. Only Canada, Mexico, Japan and the European Union offer larger markets for American goods. American private sector investment in ASEAN exceeds $\$ 800$ billion, surpassing U.S. investments in either China, Japan or India. The European Union stands as ASEAN's third largest trading partner after the United States and Japan. With a population topping 570 million, ASEAN remains of the largest regional markets in the world. (By way of comparison, the European Union has a population of some 500 million while the United States population is about 300 million.) Singapore, Brunei Darussalam and Malaysia are the fastest growing and wealthiest of the ASEAN tigers, with Myanmar (Burma) and Vietnam suffering the most repressive regimes and stagnant economies. Cambodia, Indonesia, Laos, the Philippines and Thailand find themselves in the middle of the growth spectrum. The combined GDP of ASEAN states is 870 billion euros. In comparison, the EU's GDP registers over 12 trillion euros. 3

Is the United States really a Western power? This question from a colleague originally from Uruguay, but now living and working in New York City took me aback. Had there ever been any doubt that the United States is a Western power? The frame of reference here remains NATO, consequence of World War II and the Cold War. The context deepens into the Western tradition, Western values. Primarily, the Enlightenment. Is the United States a Western Power? The question should be rephrased for today's circumstances. Is the United States a Western power in our globalized world?

Behind this question lies the assumption that geographically-designated cultural regions will become increasingly meaningless in a globalized world with the mass migration of people and information. Geographical boundaries no longer contain and isolate. With the global market, isolationism becomes self-defeating. State participation in the global market of goods and information is the key to survival. We are witnessing this in Myanmar today as it gradually begins to relax its dictatorial control and to open up. Nicolas Sarkozy, President of France, has warned Europe that it must get its financial house in order or Europe will cease to be a global actor. As Asia brings forth new sprightly tigers, upping the edge of global competition, President Obama's desire to have closer relations with Southeast Asia, and Asia generally, becomes self-evident. We are, predictably, entering the Asian Century. What state will not be interested in Asia?

At the same time globalisation is not only about commercial exchange. The world remains a dangerous place. Increased interaction demands attention to questions of law and order. Pressures of population and production will require global public policy measures to protect the earth's resources and its environment. We may even stand at the threshold of an international social contract.

The United States and Europe will be front line players in the global arena. The United States will not necessarily regret its loss of hegemony in a possible post-American world order. Former Secretary of State Robert Gates has warned that the United States can no longer afford more Iraqs. Significantly, the United Nations and Europeans participated in the 2011 Libyan operation against Quadaffi. What former U.S. President Bill Clinton

3 EUobserver.com. March 2, 2009. 
called "burden-sharing" would appear to be the wave of the future. Regional actors will be increasingly responsible for maintaining stability in their regions and thus globally. In Asia, Elizabeth Economy sees China as stepping up to bat:

For the United States, in the best case scenario, a more activist China Will share leadership with the United States and Japan, helping to forge consensus within a more active and integrated region to address its political security and economic challenges. Such an Asia would likely have a better chance of either pressuring or inducing change in some of the more recalcitrant actors in the region such as Burma and North Korea. There might also be an opportunity for regional actors to relieve the United

States of some of the burden of regional crises such as the humanitarian crisis brought on by the tsunami in South Asia in 2004, political unrest in Indonesia or in coordinating a response on transnational or global threats such as terrorism. 4

The United States also looks to Japan in this capacity. Certainly India, a vibrant democracy, will be another plausible regional actor in the Indian Ocean scenario described by Robert Kaplan. Australia has been a stalwart partner of the United States and assumedly will continue to help stabilize the "down under." It stands to reason that with the economic boom all over Asia and with its significant population mass, Asia will remain on everyone's radar.

Colonialism is dead and buried. Postcolonial theorists will have to begin rethinking the meaning of culture hybridity, even Orientalism. The new cultural adjustment demands emanate from the impact of IT which confronts us all, East and West, North and South. Whether we like it or not, we must change and adjust to our new global social intercourse. To opt out is to perish. The name of the new global game is mutual benefit, not divide and rule.

The Europeans have for some time been adjusting to the loss of their Eurocentric world. The creation of the European Union has given them a new perspective and a new mission civilisatrice - a global mission. This mission entails promoting regional integration throughout the world by peaceful measures. For the Europeans, Asia, and southeast Asia in particular, beckons - not only for its economic opportunities but for its nascent regional integration attempts in ASEAN

While the United States and Europe are often spoken of in the same breath, important differences divide these "Western powers." It is our contention here that these differences can be coordinated into a two-track global policy of global utility. Let us review the differences and then examine the global policy possibility.

\footnotetext{
4 Elizabeth Economy, 'China's Rise in Southeast Asia: Implications for the United States.' Journal of
} Contemporary China.Vol 14 No. 44, 2005, 44, p. 411. 


\section{The United States and Europe: A Historical Image}

The early leaders of the American Republic - George Washington, James Madison, Thomas Jefferson, Tom Paine, regarded Europe with great skepticism. Certainly, as revolutionaries, they saw "old Europe" as repressive and outmoded. Jefferson extolled the American experiment in "agrarian republicanism" based upon the farmer who embraced all the virtues of a true democratic citizen - independence, hard work and rationality, and warned against the over-crowded, rentier urban population of Europe. Washington counseled against "foreign entanglements" with Europe, assuming such entanglements would corrupt the American democratic experiment.

Although monarchical France assisted the Americans in their revolution, its motive was, of course, political - to damage Britain. A long-standing rivalry exists between the two countries to this very day as the outstanding Western models of revolutionary democracy. Of English origin, American democracy manifests the principles of John Locke, both in its Constitution, its social doctrine and its economic preference. The United States, as Louis Hartz reminds us in his classic work, Liberal Democracy in America, had no feudal past. The American colonists encountered a virtually pristine land -the native inhabitants of which they "subdued," a land without the weight of historical traditions, a "state of nature," as described metaphorically by Locke, which allowed for the original "social contract." Following the Lockean scheme, American democracy has emphasized unencumbered individualism, private property (of which the Whig Locke was the first apologist) and democratic governance based on separation of powers, majority rule and minority protection. American democracy, as Frederick Jackson Turner postulates, became re-enforced through the conquest of the frontier. European aristocratic titles had no meaning on the frontier. Class differences dissipated. Individualism surged. American democracy, as a model, evinced brashness, personal initiative, material conquest, and pragmatic solutions to complex social problems.

In contrast, France's democratic revolution of 1789, a civil war that, as predicted by the English parliamentarian at the time, Edmund Burke, turned into an international war under Napoleon Bonaparte, erupted within the confines of a rigid but waning feudal system. Rebelling against a class system topped by a sprawling privileged but unproductive aristocratic class, its inequities immortalized by Victor Hugo in his Les Miserables, the French revolutionaries, both of the Girondin and Jacobin persuasion, took their inspiration from the writings of Jean Jacques Rousseau. Unlike Locke, Rousseau emphasized the community rather than the individual in democracy. Public policy should put into effect what Rousseau called the volonté générale or general will, meaning the moral essence of the community as opposed to the majority rule of individual or particular wills. The abiding question as to how the general will should be discovered and articulated remains unanswered in Rousseau who, however, stipulated that those who do not align themselves with the general will should be forced to be free. 5 Basically, French democracy tends to be corporate in conception with an emphasis on the equality of the corporate members.

5 Jean-Jacques Rousseau. Social Contract. Great Books of the Western World. Robert Maynard Hutchins, ed. Encyclopaedia Britannica., Inc. Chicago. 1952 Book I. chapter 7. p. 393. 
These two models of democracy, the American and the French, persist and shape respective domestic policies and, importantly for our purposes, also foreign policy. The American critique of French colonialism in Asia, as mentioned previously, stemmed from these differences in democratic approach; the Americans have felt their model, as exhibited by their policies in the Philippines, superior. Today the United States supports a neo-liberal world order predicated upon a Westphalian state structure. Realism or the pursuit of national self-interest remains the cornerstone of this Westphalian system. While the United States has promoted world organizations like the United Nations, indeed its own President Woodrow Wilson advocated the League of Nations, it always assumes, in the spirit of Lockean social contract theory, the underlying sovereignty of the members of such world organizations. Military capability is the ultimate defense of such sovereignty and, consequently, the United States sees hard or military power as an essential ingredient of political power in the international arena.

The French model of democracy generally characterizes European states and the European Union in general. Europeans shared a common historical experience, especially $n$ their experience of feudalism. Despite his Protestant family, Rousseau regarded himself as Catholic and his thinking reflects ingredients of Catholic social philosophy which stresses government's paternalistic responsibility for the community. Europeans view the state as provider and protector. Protestant, frontier America -where the state and its law were more often than not far away and even deliberately kept at bay, emphasizes the primacy of the private sphere over that of the public. Europeans would find the notion of self reliance espoused by the New England transcendentalist, Ralph Waldo Emerson, harsh and unfair. They might even find it anarchic. Indeed Europeans visiting the United States tend to find this New World country chaotic and insubordinate - especially the jaywalking and the "open" classrooms in the schools. All European states have an infinitely more elaborate safety net system of social entitlements than the United States does. The health care issue alone demonstrates the great divide between the Europeans and Americans regarding the role of the state. In the United States a public health care system is a politically contested issue while in Europe it remains self-evident.

France spearheaded European integration. One could perhaps argue that France "subconsciously" sought to complete the work that Napoleon Bonaparte failed to accomplish - to unite Europe through the democratic ideals of 1789. Jean Monnet stands out as a, if not the, leading Europeanist and, interestingly, Monnet conceived of Europe as a "United States of Europe," a concept that the Americans latched onto. Coming from the region of Cognac where his family had a small brandy distillery, Monnet writes in his autobiography that from his earliest childhood he was exposed to foreigners who came to do business in Cognac. He also travelled on behalf of his father's business to America, which, he writes, he came to love. The upshot of this birthright, in his own words, was that Monnet did not develop strong nationalist feelings but rather felt himself an internationalist. One might argue that this sentiment revealed him as a true child of the French revolution whose ideals were meant to be universalized and qualified him, therefore, to be instrumental in the transformation of post World War II Europe. 
The concentration camps opened after World War II proved conclusively that Europe needed transformation. A moral transformation. Civilized Europe has the singular distinction of having engineered the most massive genocide in world history, thanks to its technological advancement. Felix Horkheimer in his book, The Dialectic of the Enlightenment, coined the term, "industrial genocide," to describe the massive onslaught. A German leader of Austrian origin, Adolf Hitler, conceived and implemented the genocidal policy aimed primary at Europe's Jews but which included Roma and homosexuals. The death count of six million Jews is now being corrected as mass graves of Jews are being unearthed in the Ukraine, primarily through the efforts of the French priest, Father Patrick Desbois. ${ }^{6}$ The number of dead is projected to climb at least another two million, perhaps more, as more mass grave sites in the Ukraine are discovered. And this number does not include non-Jews who were killed in the camps and elsewhere. While Germany spawned the genocidal policy, Hitler proclaimed that it would have been impossible to carry the policy out without the complicity of other European states.

As the concentration camps were opened at the close of World War II - Dachau, Bergen-Belsen, Buchenwald, Auschwitz, Theresienstadt, and "crimes against humanity" became written into international law through the Nuremberg Trials, the Holocaust, as intent and as deed, overshadowed Europe. What did European civilization mean?

Within this context European integration became a moral imperative. Integrationists excoriated nationalism as the cause of conflict and war in Europe's troubled history. Becoming economically interdependent through merged infrastructures which eventually would lead to political integration would make war undesirable and thus, hopefully, impossible. Europe would lay down its arms, reconstitute itself and become an exemplar of moral vision. Integrated Europe would embrace soft power.

\section{The European Union versus the United States}

It is no secret that the European Union faults the United States for its reliance upon hard power. The EU argues that the United States sees all political problems through the prism of the military. The Allied victory in World War II propelled the United States into a world leadership position that it had no responsible choice but to accept, especially given the onslaught of the Cold War immediately after the war. That position has not resulted in imperial conquests but has, instead, weighed heavily upon the shoulders of American citizens who pay their taxes for diverse foreign policy expenditures that include foreign aid as well as military preparedness and who have suffered the loss of family members in Korea, Vietnam, Afghanistan and Iraq, to name but the outstanding conflicts. In the aftermath of World War II foreign aid expenditures

${ }^{6} \mathrm{cf}$. P. Desbois. The Holocaust by Bullets: A Priest's Journey to Uncover the Truth behind the Murder of 1.5 Million Ukrainian Jews. New York, Palgrave Macmillan. 2009. In the forward Paul A. Shapiro writes: "The Holocaust by Bullets project has memorial and testimonial significance beyond anything we have encountered for a long time. The mass grave sites strewn across Ukraine inspire horror, but require reverence. Most of the sites will never be located if not found now, while eyewitnesses to the killings can identify them." (p. xii) 
included the Marshall Plan that allowed Europeans to rebuild and to begin integration, which the United States wholeheartedly supported and fostered.

The terrorist attack on New York City on 9/11/2001 (as well as on Washington, D.C.) traumatized the American nation. For the Bush Administration, national security became a number one priority. The Iraq invasion followed and created the great divide between Europe and the United States. Leading European intellectuals like Juergen Habermas and Jacques Derrida published on May 31, 2003 individual articles opposing the war in seven European newspapers. Millions of European citizens took to the streets in London, Paris, Berlin, Madrid, Barcelona and Rome against the war in Iraq. Elizabeth Economy cites similar reactions in Southeast Asia: "The White House doctrine of preemption, unilateralism and invasion of Iraq led to a precipitous decline in America's reputation among many publics throughout the world, including those in Southeast Asia."7

Similarly, subsequently with Afghanistan, former U.S. Secretary of Defense Gates charged that public and political opposition to the military has become so predominant in Europe that it is impeding the action in Afghanistan and adversely affecting the NATO alliance. ${ }^{8}$ According to Gates NATO is under-financed and in need of helicopters and cargo aircraft, but only 5 of the 28 NATO members have reached the established target of $2 \%$ of GDP for defense spending. The United States spends more than $4 \$$ of its GDP on military expenses.

From the American point of view, post-World War II Europe had the luxury of tending to its own economic restoration and development under the protective umbrella of the American-led NATO alliance. This remains the case. Ultimately, the United States and NATO brought the Yugoslav/Bosnia/Kosovo conflict to resolution, not the Europeans. Europeans hailed the 2008 election of Barack Obama, believing they finally had an American president who thought like them, and bestowed upon Obama the Nobel Peace Prize before he had made any world initiatives. Perhaps their enthusiasm was premature. In a New York Times op-ed Ross Douthat looked at "Obama the Realist:"

...from the war on terror to the current unrest in Egypt, his [Obama's] foreign policy has owed far more to conservative realpolitik than to any left-wing vision of international affairs.... There are moments when American presidents can afford to stand uncompromisingly with democratic revolutionaries. But they need someone to stand for. In the Soviet bloc in the1980's, Ronald Reagan had Lech Walesa, Vaclav Havel, Pope John Paul II - and ultimately Mikhail Gorbachev. In Egypt Obama has Mohammed El Baradei, the Muslim Brotherhood and the crowds: the first Dubious as grass-roots leader, the second dangerous, and the third perilously disorganized. This is a situation that calls for great caution, rather than grand idealistic gestures. And it calls for a certain measure of relief, from the American public, that this liberal president's foreign policy instincts have turned out to be so temperamentally conservative. ${ }^{9}$

\footnotetext{
7 Economy, 'China's Rise in Southeast Asia,' Journal of Contemporary China. op cit. p. 411.

8 New York Times. February 24, 2010.

9 R. Douthat, 'Obama the Realist,' New York Times. Op-ed February 7, 2011. p A23
} 
We intend no evaluation of President Obama here. The point to be made is that in an idealistic world we would, no doubt, all relish the absence of military (hard) power. We do not, however, inhabit such a world. Though soft power advocates tend to assume that they walk the moral high ground, great harm and injustice can be done by a failure to act, also militarily. Times and situations pertain when moral duty requires the call to arms. Indeed we have a rich legacy of international jurisprudence regarding the circumstances and conditions of just war.

\section{A Two Track Policy}

To depict our present day world as a Manichean choice between soft power and hard power appears unrealistic in the extreme. Janice Bially Mattern breaks ground with her trenchant analysis of soft power conceptually and operationally. Mattern defines soft power as the attempt to achieve desired outcomes through attraction rather than through coercion. ${ }^{10}$ Attraction can be either natural or the result of persuasive argument. Neither of these forms of attraction, argues Mattern, is feasible in world politics. For attraction to be effective politically, it should rather be modeled as a relationship through representational force. Mattern portrays this representational force as a non-physical but nevertheless coercive form of power conveyed through language. In her analysis Mattern rejects the notion that soft power stands diametrically opposed to hard power. Rather soft power is a continuation of hard power by other means.

An example of representational force might be the so-called element clause in European Union development treaties like the Euro-Mediterranean Partnership (EMP 1990) or the more recent Union for the Mediterranean (UPM 2008). The element clause constitutes a sanction clause. Development aid will be interrupted if democratic reforms or protection of human rights, for example, do not proceed. Criticism has been leveled against Europe for overlooking human rights violations in order to avoid enforcing the element clause.

Another term for soft power that is gaining currency is normative power. The concept of normative power and a normative actor is assiduously analyzed in Nathalie Tocci's edited volume, Who is a Normative Foreign Policy Actor? The European Union and Its Global Partners. ${ }^{11}$ The European Union, the United States, Russia, China and India are prominent actors discussed. The conclusion drawn from the discussion in this book is that all states think of themselves as pursuing a normative foreign policy. Clearly, there are various interpretations of what normative really means or entails. Normative always reflects norms or values. A normative foreign policy may, however, be one that wants to change the prevailing value system internationally. Or, then again, it may indicate a compliance with stipulated norms while, possibly, a rejection of other norms. It does not

${ }^{10} \mathrm{cf}$. J.B. Mattern, 'Why 'Soft Power' Isn't so Soft: Representational Force and the Sociolinguistic Construction of Attraction in World Politics,' in Millennium: Journal of International Studies. Vol. 33. No. 3, 2005. pp. 583-612.

${ }_{11} \mathrm{cf}$. Nathalie Tocci (ed.), Who is a Normative Foreign Policy Actor? The European Union and Its Global Partners. Centre for European Policy Studies, Brussels, 2008. 
necessarily manifest itself as a preference for soft power. The United States, for example, believes it follows a normative foreign policy predicated upon the pursuit of democratic and neoliberal values internationally but employs hard power in certain given circumstances (like Iraq).

In contradistinction, the European Union sees itself as a soft and normative power. Moreover, it links these attributes to yet a third defining characteristic, namely, multilateralism. Economically, multilateralism refers to the convertibility of national currencies on a non-discriminatory basis. The G-20 stands as the principal forum for coordinating the international economy. In 2009 the G-20 created the Financial Stability Board to strengthen the standards for international finance.

Within international treaty regimes multilateralism designates investment in the creation and maintenance of international institutions and compliance with the rules, norms, principles, and decision-making processes of such institutions. Multilateralism becomes conceptually cloudy in the realm of political action, including military intervention. Minimalists like Robert Keohane define multilateralism as an international decision-making process that involves three or more states either on an ad hoc basis or institutionalized. Other scholars seek to enrich this minimalist definition by adding qualifiers. For example, actors in a multilateral decision-making structure should involve a mix of greater and lesser powers. Three or more Great Powers making a decision that affects lesser powers lacks the moral ingredient, according to this argument, that some wish to convey with multilateralism. Military intervention poses particular problems for defining multilateralism. Did the few hundred troops contributed by Barbados, Dominica, Jamaica and St. Lucia to the American intervention in Grenada make this a multilateral action?

From the European point-of-view multilateralism entails not only membership in international organizations like the United Nations. It also requires that states be signatories to international treaties like the Kyoto Treaty (environmental regulations) and the International Criminal Court. By this standard the United States does not behave multilaterally. The European Union sees the United States as a unilateralist, a perspective not necessarily accepted by the United States itself. Europeans complain that the United States does not consult with them more and on a regular basis regarding American strategic policy and decisions. This complaint widens the meaning of multilateralism to include routine consultation among allies.

The differences between Europe and the United States are real but not insurmountable. Their differences are akin to sibling rivalry. Some Europeans would vehemently disagree with this assessment, claiming, rather, that these two powers live in two separate ideational worlds. Indeed for some Europeans anti-Americanism has been elevated to an identity marker. As Andrei Markovits posits, in still fractured Europe, antiAmericanism serves as the most reliable glue for achieving a common European identity. ${ }^{12}$ Robert Kagan has a point in stating that Europeans miscalculated, to their

12 cf. A. S. Markovits. Uncouth Nation: Why Europe Dislikes Americans. Princeton University Press, 2007. 
detriment, the post-World War II importance of economic power. 13 The 2011 euro crisis, to which we shall return, has sapped Europe's political confidence and its sense of self. The United States continues to loom in European memory as the Great Protector from whom it does not seem to be able to lose itself. Jeremy Shapiro and Nick Whitney, writing for the European Council on Foreign Relations, mince no words when they describe "...the European attitude to the United States as infantile and fetishistic."14 They continue: "... the idea that the future of the relationship in which they [Europeans] are so heavily invested lies in their own hands will not be easy to accept. America wants to be Europe's partner, not its patron; but it cannot be responsible from without for weaning Europe off its client status."15

We live in a fast changing world in which new power strategies must be devised and employed. Soft power alone, just as hard power alone, does not suffice and is thus ineffective. Joseph S. Nye, Jr. stipulates that "the coming decades are not likely to see a post-American world, but the United States will need a smart strategy that combines hard- and soft- power resources - and that emphasizes alliances and networks that are responsive to the next context of a global information age."16 Publishing an article in Foreign Affairs, thereby signalling a policy statement, U.S. Secretary of State Hillary Clinton announced the new "public diplomacy strategy" of the United States. Clinton writes:

In this information age, public opinion takes on added importance even in authoritarian states and as nonstate actors are more able to influence current events. Today a US ambassador creates ties not only with the host nation's government but also with its people. The QDDR (Quadrennial Diplomacy and Development Review in the State Department) endorses a new public diplomacy strategy that makes public engagement every diplomat's duty, through town-hall meetings and interviews with the media, organized outreach, events in provincial towns and smaller communities, student exchange programs and virtual connections that bring together citizens and civic organizations. Indeed, in the twenty-first century, a diplomat is as likely to meet with a tribal elder in a rural village as a counterpart in a foreign ministry, and is as likely to wear cargo-pants as a pinstriped suit. ${ }^{17}$

Clinton uses the term "civilian power" to designate the new public diplomacy, a term that once was a part of the European Union's vocabulary when it was still the European Community. Can the United States and the European Union form a partnership based on a two-track policy of cooperative hard and soft power, multilateralism and realism?

13 cf. R. Kagan. Of Paradise and Power, New York, Alfred A. Knopf. 2003.

14 J. Shapiro and N. Whitney. Towards a Post-American Europe: A Power Audit of EU-US Relations. European Council on Foreign Relations, October 2009. p. 61.

15 Ibid.

${ }^{16}$ J. S. Nye, Jr. 'The Future of American Power: Dominance and Decline in Perspective,' Foreign Affairs.

November/December 2010. p. 12.

${ }_{17}$ Hillary Rodham Clinton. 'Leading Through Civilian Power: Redefining American Diplomacy and Development.,' Foreign Affairs. November/December 2010. p. 16. 


\section{Two Tracks and Asia}

The European Union looks with great interest at the regional integration efforts in Southeast Asia. Could ASEAN become the European Union of Southeast Asia? As mentioned, Europeans see regional integration as the pathway to global peace and economic prosperity. European development funds are channelled into projects abroad which foster such regional integration - like ASEAN. In 2007 the European Union signed the Nuremberg Declaration with ASEAN which commits both parties to cooperating in political, security, economic, socio-cultural and economic development as well as in the fields of energy security and the environment.

ASEAN members, however, reject the European Union as the model for regional integration. For Asians, the European Union is a model for regional integration but not the model. With their own tumultuous histories that include imperial/colonial subjection and with highly diverse populations including conflictual ethnic minorities in still weak states, ASEAN states seek to preserve and strengthen their own newly acquired national sovereignty. In its most recent 2011 skirmish with Cambodia over the Preah Vihear temple site, Thailand insisted upon dealing with Cambodia on a bilateral basis and refused the intervention of outside organizations like the U.N. Security Council. ASEAN states do not aspire to any kind of multilateral organization like NATO. Quite the contrary. Furthermore, ASEAN states insist upon sovereign currencies. They fault Europe's common currency for confounding Europe's ability to deal with the current euro crisis and credit the sovereign currencies of ASEAN for ASEAN states' relatively swift recovery from the recession.

Moreover, while Europeans criticize the United States for its hard power approach to political problems, ASEAN puts Europe to the test. Amitav Acharya writes in this regard:

Asia's regional institutions are often dismissed by many Western critics as 'talk shops' but European regional institutions are not without shortcomings and limitations as well. The Russian invasion of Georgia, following conflicts in Bosnia and Kosovo, shows that peace in Europe can not be taken for granted, while stability in Asia, where no major war has taken place since 1979 (with the exception of the India-Pakistan conflict over Kargil) can be understated. The Georgian crisis also says something about EU and OSCE (Organisation of Security and Cooperation in Europe) which despite the elaborate toolkit of confidence-building, preventive diplomacy, early warning mechanisms, failed to prevent what may turn out to be the most serious breach of international order since the USinvasion of Iraq. By contrast, Asia's supposedly weak and ineffectual talk shops, by discouraging an American-led containment of China, by making multilateralism palatable to Beijing and using the resulting Sino-US restraint to soften the region's balance of power geopolitics, have prevented a Georgia in the region. ${ }^{18}$

\footnotetext{
${ }^{18}$ A. Acharya. Regionalism and Integration EU and Southeast Asia Experiences. International Cultural
} Dialogue. Bertelsmann Stiftung. (No publication year listed.) 
ASEAN continues to think in terms of the Westphalian state. For Asia, especially Southeast Asia, the soft power, multilateral model of the European Union has economic attraction, with the exception of the common currency, but limited political attraction. The European Union is seen as a "peace investor" and "peace facilitator," investing in economic development, good governance, human rights and democracy promotion. An example of this would be the Partnership for Democratic Local Governance in Southeast Asia (DELGOSEA), funded by the European Commission and the Konrad Adenauer Stiftung of Germany and launched in March 2010 to exchange good governance practices on the local level in the Philippines, Indonesia, Vietnam, Thailand and Cambodia.

Were Europeans to use soft power as a stimulus for regional integration in Asia à la Europe, they would find themselves not only rebuffed but considered in violation of national sovereignty, of interfering with Asian states' internal affairs. Here we have a perfect example of Janice Bially Mattern's ethical dilemma regarding soft power. Mattern writes: "In my opinion a power politics of identity, however unappealing, is normatively more appealing that the power politics of war, empire and physical conquest. But even so, one must still question the moral logic of representational force. Given that soft power may, in the end, not be all that soft, it is worth considering the ethical dimensions and dilemmas that arise when using it as a "means to success in world politics."”19

ASEAN states continue to look to the United States for hard power security. Such security relates primarily to China. Elizabeth Economy, however, warns that the United States must be ever mindful of its own strategic interests since the "China card" may also be used against the United States, especially as an outside regional actor. As Stewart Patrick states: "There is, of course, no common worldview among today's emerging countries. But as U.S. power declines, the rising powers will seek to test, dilute, or revise existing institutions to suit their purposes. The United States will need to decide when to stand firm, when to engage, and when simply to agree to disagree." 20

Asia demands strategies and employments of mixed power - hard and soft. It favors regional cooperation and limited integration. It emphasizes national sovereignty and bilateralism. It wants, like the European Union and the United States, open markets and open seas. Perhaps, as Kant envisioned, free trade will result in free governance globally.

The conclusion seems inescapable. Mutual benefit is the calling card of our globalized world. In partnership, the European Union and the United States can be a force for enormous benefit for themselves and for others. Those Euroskeptics who see the present euro crisis as the collapse not only of Euroland but of the European Union itself will be sorely disappointed. The crisis - though certainly severe in terms of the bailouts for Ireland, Greece and Spain, with Italy not far behind, has in fact prompted the next step in political integration. Recognizing that Europe cannot be allowed to "go under,"

\footnotetext{
19 Mattern. op. cit.. pp. 611-12.

${ }^{20}$ S. Patrick. "Irresponsible Stakeholders? The Difficulty of Integrating Rising Powers." Foreign Affairs. November/December 2010. p. 50.
} 
Sarkozy of France and Merkel of Germany now call for the empowerment of the European Central Bank and a tightening of across-the-board fiscal regulations. Europe will more than survive; it will grow, though the road be rocky.

The United States and the European Union, even in a post-Eurocentric world, still constitute the most formidable economic, social and political power hubs. They have much to offer the world. The world can only benefit from the partnership of the United States and Europe that allows each to contribute its own specialty and genius to the development and well-being of others and, in return, benefit themselves from an open global exchange. At the same time cooperation between the United States and Europe will enhance these partners who have shared so much over more than two centuries.

The problem with Realism is that it got stuck in the state-of-nature depiction of Thomas Hobbes as a "bellum omnium contra omnes - a war of all against all." Modern evolutionary biology informs us that the secret of homo sapiens' evolutionary success lies in the species' cooperative spirit. John Locke implicitly understood this. Liberal democracy would be impossible without this cooperative spirit, this ability to build social capital. Locke depicted the state of nature not as a situation of war but as a situation of inconvenience - individuals had to do everything, including defending their rights, on their own in the state of nature. The rational solution of peaceable, rational individuals was the state, basically a contractual division of labor that made life so much simpler by allowing individuals to take advantage of the skills of others like farmers, carpenters, weavers -- and governing representatives, to supply and take care of their daily needs so that they could think about developing themselves in whatever way they chose. Consider this description of our global world. The newest aspect of globalization is global manufacturing supply services where a "Malaysian architect will sketch out a new office tower for London, a Philippine architect will prepare detailed renderings, and a Chinese engineer will assess the structural soundness of the designs." ${ }^{21}$ Does this not sound like Locke's idea of the state as a division of labor? Has the global society not become a global division of labor? We increasingly live in a world in which cooperation, not conflict, is the key to success. Can an international social contract be far behind? Does an American-European partnership not make sense?

${ }^{21}$ J. Sternberg, 'Now Comes the Global Revolution in Services,' New York Times. February 10, 2010. p. A17. 